\title{
RANTAI NILAI PRODUK BUDIDAYA RUMPUT LAUT DI DESA BUKU UTARA KECAMATAN BELANG KABUPATEN MINAHASA TENGGARA
}

\author{
Wandris G.F. Bilangua'; Lexy K. Rarung'; Otniel Pontoh ${ }^{2}$ \\ 1)Mahasiswa Fakultas Perikanan dan IImu Kelautan Universitas Sam Ratulangi Manado \\ 2)Staff Pengajar Fakultas Perikanan dan IImu Kelautan Universitas Sam Ratulangi Manado \\ Koresponden email : glendyfalen97@gmail.com
}

\begin{abstract}
This study aims to want to know the value chain of seaweed cultivation products from the first seller or seaweed cultivator to the last buyer and identify the value chain of seaweed cultivation products in North Buku Village of Belang District, Southeast Minahasa Regency. The result shows that the value chain research on seaweed cultivation products starting from the farmers who cultivation the seaweed. The office of marine fisheries Province bought 2 tons per season and the price of seaweed is $R p .7500,-/ \mathrm{kg}$, so the total of 2,000 $\mathrm{kg} \times R p$ 7500,- are Rp. 15,000,000,-. Where as for dried, sold Mahau store Rp. 20,000.,-/kg as much as $200 \mathrm{~kg}$ per season, so the total for drying seaweed are Rp 4,000,-
\end{abstract}

Keywords: Buku village, value chain, seaweed

\begin{abstract}
Abstrak
Penelitian ini bertujuan untuk mengetahui rantai nilai produk budidaya rumput laut mulai dari penjual pertama atau pembudidaya rumput laut sampai pada pembeli terakhir dan mengidentifikasi rantai nilai produk budidaya rumput laut di Desa Buku Utara Kecamatan Belang Kabupaten Minahasa Tenggara. Berdasarkan hasil penelitian rantai nilai produk budidaya rumput laut yang ada di Desa Buku Utara Kecamatan Belang Kabupaten Minahasa Tenggara, mulai dari petani rumput yang membudidaya rumput laut tersebut, kemuadian Dinas Perikanan Provinsi membeli rumput laut sebanyak 2 ton per musim (rumput laut basah) dengan harga Rp $7500,-/ \mathrm{kg}$, jadi total $2.000 \mathrm{~kg} \times \mathrm{Rp}$ $7500,-=$ Rp 15.000.000,-. Sedangkan untuk rumput laut kering dijual ke toko Mahau dengan harga Rp 20.000,-/kg sebanyak $200 \mathrm{~kg}$ rumput laut per musim, jadi totalnya untuk rumput laut kering Rp 4.000,-.
\end{abstract}

Kata kunci : Desa Buku, rantai nilai, rumput laut

\section{PENDAHULUAN}

Sulawesi Utara merupakan salah satu provinsi di Indonesia yang memiliki potensi perikanan dan kelautan yang besar. Provinsi ini telah menjadikan hasil usaha perikanan dan kelautan sebagai salah satu produk unggulan untuk memacu peningkatan Pendapatan Asli Daerah. Dengan mengetahui potensi sumberdaya perikanan dan Kelautan yang besar maka pemerintah menetapkan sub sektor perikanan sebagai salah satu sektor utama pembangunan (Kenanga, 2012).

Rumput laut merupakan salah satu sumberdaya hayati yang terdapat di wilayah pesisir. Rumput laut tumbuh hampir di seluruh bagian permukaan laut sampai batas kedalaman 200 meter. Di kedalaman ini, tanaman air masih memungkinkan untuk hidup. Karena tidak mempunyai akar, rumput laut menempel pada substratnya dan seluruh bagian talus mengambil makanan dari air yang ada di sekitarnya dengan cara osmosis (Aulia, 2015).

Rumput laut telah lama digunakan sebagai makanan maupun obat-obatan di negeri Jepang, Cina, Eropa maupun Amerika. Diantaranya sebagai nori, kombu, puding atau dalam bentuk hidangan lainnya seperti sop, saus dan dalam bentuk mentah sebagai sayuran. Di Indonesia, rumput laut telah dimanfaatkan sebagai sayuran, sejak ratusan tahun yang lalu. Pemanfaatan rumput laut sebagai makanan karena mempunyai gizi yang cukup tinggi yang sebagian besar terdapat pada karbohidrat di samping lemak dan protein yang terdapat di dalamnya. Karbohidrat dari rumput laut sukar diuraikan oleh enzim pencernaan, karena itu, sebagian besar rumput laut dimanfaatkan sebagai bahan tambahan dalam industri makanan, obat-obatan dan kosmetika (Aulia, 2015). 


\section{METODE PENELITIAN}

Dasar penelitian yang digunakan adalah studi kasus, studi kasus merupakan penelitian yang dilakukan dengan cara mempelajari kasus tertentu dan pada objek yang terbatas (Mantjoro, 1981). Dalam hal ini studi kasus yang diteliti adalah rantai nilai produk budidaya rumput laut.

Pengumpulan data dilakukan dengan cara observasi langsung atau pengamatan secara langsung pada responden yang dijadikan objek penelitian. Data yang dikumpulkan meliputi data primer dan data sekunder. Data primer adalah data yang diperoleh langsung dari responden (Sekaran, 2011). Responden dalam penelitian ini terdiri dari: 1) Petani/pembudidaya; 2) Pembeli/pedagang pengumpul; 3) Pembeli (Dinas Perikanan Provinsi Sulawesi Utara).

Dalam Penelitian ini data primer diperoleh melalui observasi, wawancara responden, pengisisan kuisioner dan dokumentasi, sedangkan data Sekunder adalah sumber data yang tidak langsung memberikan data kepada pengumpul data, misalnya lewat orang lain atau dokumen (Sugiono, 2008).

Analisis data yang digunakan dalam penelitian iní adalah analisis deskriptif kualitatif. Analisis deskriptif kualitatif yaitu analisis dengan memberikan gambaran serta keterangan dengan menggunakan kalimat penulis secara sistematis dan mudah dimengerti sesuai dengan data yang diperoleh tentang rantai nilai produk budidaya rumput laut (Hayami dkk., 1987). Analisis deskriptif kuatitaf yaitu analisis dengan menggunakan matematik sederhanana. Seperti penjumlahan, perkalian, dan pembagian.

\section{HASIL DAN PEMBAHASAN}

\section{Rantai Nilai}

Berdasarkan hasil penelitian rantai nilai produk budidaya rumput laut yang ada di Desa Buku Utara Kecamatan Belang Kabupaten Minahasa Tenggara, dapat dilihat pada Gambar 1.

1. Petani Rumput yang membudidaya rumput laut tersebut, Kemudian ada;

2. Pemanenan rumput laut untuk dikeringkan (rumput laut kering).

3. Penjumuran, rumput laut yang sudah dipanen, dijemur hingga kering.

4. Pengepakan, rumput laut yang sudah dikeringkan kemudian dipak menggunakan karung plastik.

5. Pengangkutan, setelah rumput laut selesai dipak, kemudian dimasukan ke dalam mobil untuk dibawa ke tempat penjualan.

6. Toko Mahawu, toko ini yang biasa membeli rumput laut tersebut

7. Pemanenan rumput laut untuk dijual mentah (rumput laut basah).

8. Pengepakan, setelah rumput laut dipanen, kemudian ditimbang menggunakan timbangan gantung, selanjutnya dipak menggunakan karung plastik atau terpal.

9. Pengangkutan, setelah rumput laut dipak, kemudian dimasukan ke dalam mobil angkutan.

10. Masyarakat, adalah kelompok yang menerima bantuan dari Dinas Perikanan Provinsi Sulawesi Utara. 


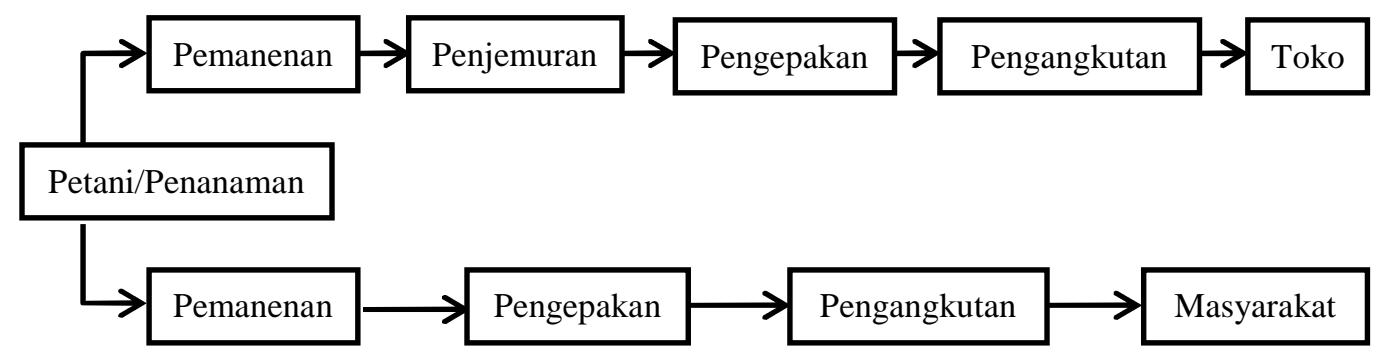

Gambar 1. Rantai Nilai Produk Budidaya Rumput Laut

Toko Mahawu membeli rumput laut dengan harga $\mathrm{Rp} 20.000,-/ \mathrm{kg}$ sebanyak $200 \mathrm{~kg}$ per musim, jadi total untuk rumput laut kering Rp 4.000,000,-. Dinas Perikanan Provinsi membelirumput laut sebanyak 2 ton per musim (rumput laut basah) dengan harga $7500,-/ \mathrm{kg}$, jadi total $2000 \mathrm{~kg} \times \mathrm{Rp}$ $7500,-=$ Rp 15.000.000,-. Adapun biayabiaya yang harus dikeluarkan pada waktu penanaman sampai pada penjualan, penanaman rumput laut biasanya dilakukan pada pagi hari, mulai dari pengikatan bibit sampai pengikatan tali ris.
Pada saat petani rumput laut mulai melakukan penanaman dengan besar lahan $100 \times 200$ meter petani tersebut pasti memerlukan tenaga kerja yang harus dibayar per hari walaupun pekerjaan yang dilakukan hanya beberapa jam saja, hal ini dikarenakan mereka harus mengorbankan pekerjaan lain, misalnya, pekerjaan mereka setiap hari bertani atau melaut untuk menangkap ikan tetapi dengan tawaran pekerjaan lain yang mereka pertimbangkan lebih menguntungkan dan waktunya hanya beberapa jam saja, jadi sisa waktu dalam sehari mereka bisa menggunakannya untuk beristirahat.

Tabel 1. Rantai Nilai Rumput Laut

\begin{tabular}{|c|c|c|c|c|c|c|c|}
\hline No & Pemanenan Rumput Laut & 1 & 2 & 3 & 4 & 5 & Jumlah \\
\hline \multirow[t]{4}{*}{1} & Rumput Laut Kering & Pemanenan & Penjemuran & Pengepakan & Pengangkutan & $\begin{array}{c}\text { Tokol } \\
\text { masyarakat }\end{array}$ & \\
\hline & Jumlah Tenaga kerja & 3 orang & 3 orang & 3 orang & 3 orang & 3 orang & 3 orang \\
\hline & Lama bekerja (hari) & 1 hari & $\begin{array}{c}3 \text { hari + } \\
\text { pemanenan }\end{array}$ & $\begin{array}{c}1 \text { hari }+ \\
\text { Pengangaku } \\
\text { tan +Toko }\end{array}$ & $\checkmark$ & $\checkmark$ & 4 hari \\
\hline & $\begin{array}{l}\text { Upah/hari Rp 150.000 (Per } \\
\text { orang) }\end{array}$ & $\checkmark$ & $1.350,000$ & 450.000 & $\checkmark$ & $\checkmark$ & $1.800,-$ \\
\hline \multirow[t]{4}{*}{2} & Rumput Laut Basah & & & & & & \\
\hline & Jumlah tenaga kerja & 3 orang & - & 3 orang & 3 orang & 3 orang & 3 orang \\
\hline & Lama bekerja (hari) & 1 hari & - & $\checkmark$ & $\checkmark$ & $\checkmark$ & 1 Hari \\
\hline & $\begin{array}{l}\text { Upah/hari Rp } 150.000 \text { (per } \\
\text { orang) }\end{array}$ & 450.000 & - & $\checkmark$ & $\checkmark$ & $\checkmark$ & 450.000 \\
\hline \multirow[t]{3}{*}{3} & Biaya Lain & & & & & & \\
\hline & Sewa mobil angkutan & & & & & & 350.000 \\
\hline & Biaya penanaman & & & & & & 300.000 \\
\hline
\end{tabular}

Sumber : Data Primer, 2018

Upah tenaga kerja yang dibayar oleh petani rumput laut per hari sebesar Rp 150.000,- per orang/per individu. Untuk penanaman petani rumput laut menggunakan dua tenaga kerja sedangkan untuk pemanenan, penjumuran sampai pengepakan, petani tersebut menggunakan tenaga kerja sebanyak tiga orang. Sedangkan untuk pengiriman produk rumput laut kering petani rumput laut membayar mobil pinjaman sebesar Rp 350.000,- untuk 
satu kali pengiriman menggunakan mobil angkutan.

Petani rumput laut membayar orang atau mempekerjakan orang dengan upah yang suda ditentukan, untuk dapat membantu agar perekonomian keluarga dapat berjalan dengan baik. Hal ini memiliki nilai yang sangat tinggi bagi roda perekonomi keluarga yang ada di Desa Buku Utara, karena petani rumput laut tersebut dapat membuka lapangan pekerjaan bagi orang-orang yang ada di sekitarnya, meskipun lapangan pekerjaan itu hanya pekerjaan sampingan akan tetapi itu sudah sangat bermanfaat bagi para pekerja.

Dalam waktu satu bulan petani rumput laut mengeluarkan uang sebesar Rp 800.000,- - Rp 2.150.000,- untuk biaya jasa yang dipakai meskipun dalam waktu tersebut hanya 2-3 hari saja bekerja.

Sedangkan untuk pedagang pengumpul pada dasarnya pedagang pengumpul selalu menerima produk yang dibawa langsung ke tempat, tidak mendatangi petani rumput laut tetapi pedagang pengumpul memerlukan tenaga kerja untuk melancarkan proses transaksi antara penjual dan pembeli, mulai dari penimbangan produk, gudang penampungan bahkan sampai pada proses pengepakan untuk dijual kembali rumput laut tersebut.

Untuk pembeli (Dinas Perikanan Provinsi) berperan penting bagi masyarakat khususnya petani rumput laut yang pada umumnya petani rumput tidak memiliki modal usaha. Dengan adanya bantuan dari Dinas Perikanan Provinsi Sulawesi Utara, petani rumput laut dapat mengembangakan bantuan rumput laut tersebut untuk menambah pendapatan mereka. Bantuan yang diberikan \pm 2 ton untuk satu kelompok pembudidaya. Satu kelompok pembudidaya terdiri dari 10 anggota kelompok.

Rumput laut sebanyak 2 ton didistribusikan kepada pembudidaya/ kelompok tani rumput laut sebagai bantuan dari Dinas Perikanan Provinsi untuk dikembangkan. Bantuan tersebut tidak hanya diberikan kepada pembudidaya rumput laut yang ada di beberapa tempat, tetapi diberikan juga kepada Fakultas Perikanan dan IImu Kelautan Universitas Sam Ratulangai untuk dikembangkan sebagai bahan penelitian. Tetapi pembudidaya/petani rumput laut jarang menjual rumput laut kering karena perbedaan keuntungan, rumput laut basah lebih menguntung dibandingkan dengan rumput laut kering jika dijual, meskipun rumput laut kering lebih mahal harganya dibandingkan rumput Naut basah. Hal ini dikarenakan perbedaan berat dalam satuan $(\mathrm{kg})$, untuk 1 ton rumput laut basah harganya $\pm \mathrm{Rp}$ 7.500.000,- jika dibandingkan dengan rumput laut kering, untuk 1 ton rumput laut basah jika dikeringkan maka tinggal $100 \mathrm{~kg}$, jadi harganya $\pm \mathrm{Rp}$ 2.000.000,-. Dengan alasan ini Pak Daud Soleman menjual rumput laut kering jika tidak ada pembeli rumput laut basah atau Pak Daud Soleman menjual rumput laut kering hanya karena keadaan terpaksa, atau tidak ada pembeli rumput laut basah. Adapun berdasarkan rantai tataniaga produk budidaya rumput laut di Desa Buku Utara Kecamatan Belang Kabupaten Minahasa Tenggara.

\section{Petani Rumput Laut}

Petani rumput laut berperan sebagai produsen dengan komoditi yang diusahakan dari hasil perikanan. Petani rumput laut yang ada di Desa Buku Utara apabila menjual hasil panen 
rumput lautnya, petani menjual rumput lautnya secara tunai karena di Provinsi Sulawesi Utara khususnya Kabupaten Minahasa Tenggara hanya terdapat 1 orang pembudidaya/petani rumput laut. Hal ini yang membuat harga rumput laut di Provinsi Sulawesi Utara ini meningkat, yang dulunya hanya sebesar Rp 5.000,- Rp 6.000,-/kg sekarang sudah mencapi Rp 7.500,-/kg untuk rumput laut basah. Sebagai produsen tunggal di Desa Buku Utara tidak bisa menentukan harga, karena produsen tersebut tidak mempunyai kekuatan untuk menjadi price maker.

\section{Pedagang Pengumpul}

Pedagang pengumpul merupakan badan atau orang pribadi yang kegiatan usahanya mengumpulkan hasil (rumput laut) dan menjual kepada badan usaha industri atau ekspotir yang bergerak dalam sektor perikanan. Rumput laut setelah dibeli dari pembudidaya selanjutnya rumput laut tersebut dapat disimpan di dalam gudang, dipak agar tidak mengalami kerusakan dan tidak terjadi penurunan mutu, barulah rumput laut tersebut dipasarkan atau dijual kembali oleh pedagang pengumpul.

\section{Pembeli Rumput Laut Basah}

Dinas Perikanan Provinsi merupakan suatu lembaga yang membeli rumput laut dari produsen (petani rumput laut) untuk didistribusikan langsung pada masyarakat yang menerima bantuan untuk dibudiya kembali, guna untuk meningkatkan tingkat kesejahtraan masyarakat pembudidaya rumput laut tersebut.

Rumput laut setelah dipanen oleh pembudidya, kemudian dijual pedagang pengumpul atau pembeli bahkan dijual langsung ke perusahaan yang mengelolah produk rumput laut tersebut, tergantung pembudidaya yang ingin memasarkannya. Tetapi biasanya yang dilakukan oleh pembudidaya adalah menjual kepada pembeli (Dinas Perikanan Provinsi) dan pedagang pengumpul. Dari pedagang pengumpul kemudian dijual kembali ke pabrik/perusahaan yang mengelolah produk rumput laut tersebut. Begitu juga dengan pembeli dalam hal ini Dinas Perikanan Provinsi, lebih jelasnya dapat dilihat pada Gambar 2.

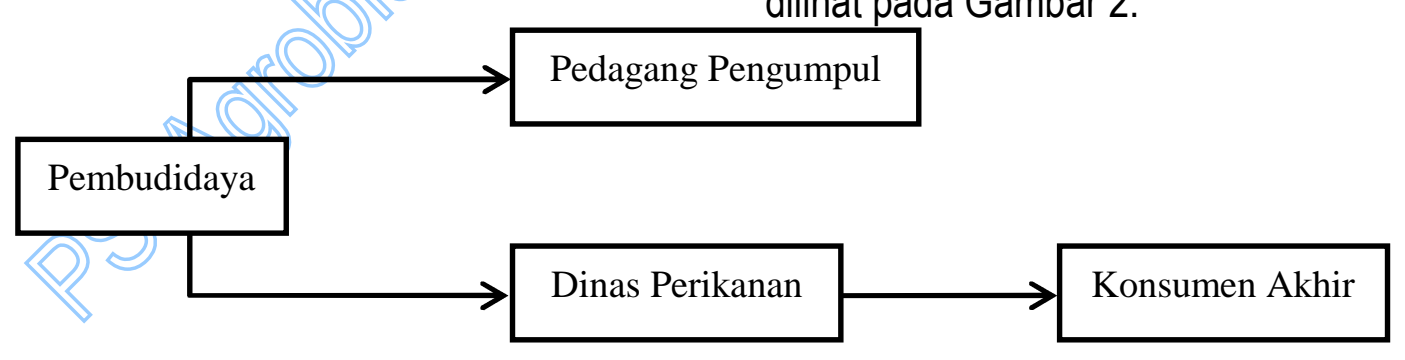

Gambar 2. Struktur Pemasaran rumput laut di Desa Buku Utara

\section{Identifikasi Rantai Nilai Produk Budidaya Rumput Laut}

Berdasarkan hasil penelitian cahaya matahari secara langsung, pembeli mengambil rumput laut pada pukul 08:00-11:00 untuk rumput laut basah, memerlukan waktu yang cukup lama karna rumput laut harus dipanen dahulu. Rumput laut tidak boleh terkena karena rumput laut tersebut akan dijadikan bibit untuk dibudidayakan kembali. Aktivitas dilakukan dengan kendaraan pribadi (pick up), untuk mempertahankan kualitas rumput laut 
(basah) biasanya langsung dimuat ke mobil dan transaksinya juga tidak lama. Tetapi kadang harus dipak dahulu dalam karung plastik barulah dimasukan dan disusun di mobil yang sudah dialas dengan terpal, setelah itu ditutup kembali dengan terpal tujuannya agar tidak terkena langsung oleh sinar matahari. Pemanenan rumput laut biasayanya menggunakan jasa anak laki-laki dari Bapak Daud Soleman (petani/pembudidaya rumput laut) tersebut sebanyak 3 orang untuk melakukan pemanenan sampai pada pengepakan dalam mobil.

Sedangkan

pedagang pengumpul atau untuk rumput laut kering waktunya tidak dibatasi baik pagi, siang, ataupun sore hari. pengambilan rumput laut dilakukan di rumah produsen (petani rumput laut) dengan kesepakatan harga yang sudah ditentukan. Berdasarkan hasil penelitian di Desa Buku Utara pedagang rumput laut membeli langsung pada produsen/petani rumput laut (dalam hal ini Bapak Daud Soleman), jual beli hanya terjadi setelah ada persetujuan harga antara pedagang rumput laut dengan produsen/petani rumput laut, yang tentunya saling menguntungkan bagi kedua pihak tersebut.

\section{Kualitas Produk}

Kualitas produk sangat berpengaruh pada dunia pemaaran, di mana kualitas produk yang menentukan harga jual mahal tidaknya suatu produk dalam hal ini rumput laut. Berdasarkan hasil penelitian, rumput laut dibagi menjadi dua bagian yaitu rumput laut basah dan rumput laut kering.

1. Rumput laut basah biasanya terdapat pada rantai pertama yaitu pada petani/pembudidaya rumput laut, jika rumput lautnya subur, tidak terkena penyakit (ice-ice) harganya juga lebih mahal dibandingkan dengan yang terkena penyakit, karena rumput laut basah biasanya dibeli untuk dibudidaya kembali atau digunakan untuk pembibitan.

2. Rumput laut kering biasanya terdapat pada rantai pertama (pembudidaya) dan rantai-rantai berikutnya (pedagang pengumpul sampai ke konsumen berikutnya bahkan sampai ke pabrik pengelolah). Di setiap rantai kualitas rumput laut harus dipertahankan agar tidak mengalami kerugian, karena rumput mudah mengalami kelembaban jika tidak disimpan di tempat yang aman.

\section{Wilayah Pemasaran}

Pemasaran hasil kelautan dan perikanan yaitu semua jenis usaha yang ditujukan untuk menyalurkan berbagai jenis hasil perikanan dari nelayan/petani (rumput laut) selaku produsen hingga ke tangan konsumen. Berdasarkan hasil penelitian wilayah pemasaran rumput laut dari tiap-tiap responden adalah sebagai berikut.

1. Pembudidaya/petani rumput laut

Wilayah pemasaran hasil budidaya rumput laut oleh pembudidaya biasanya dipasarkan dalam provinsi saja. Akan tetapi perna ada pembeli asing berkewarganegaraan Tailand yang mendatangi langsung pembudidaya (Bapak Daud Soleman) untuk membeli rumput laut tersebut. Tetapi yang paling sering, rumput laut Bapak Daud Soleman ini biasanya dibeli oleh Dinas Perikanan Provinsi Sulawesi Utara untuk rumput laut basah. Sedangkan rumput laut kering biasanya dijual ke Toko Mahawu.

2. Pedagang Pengumpul (rumput laut kering) 
Wilayah pemasaran pedagang pengumpul ini di luar daerah, tergantung harga yang ditawarkan oleh masing-masing daerah, karena di beberapa daerah harganya berbeda-beda. Bukan hanya di dalam negeri saja wilayah pemasaran pedagang pengumpul ini, bahkan sampai keluar negeri jika rumput lautnya banyak.

3. Pembeli (Dinas Perikanan Provinsi)

Dinas Perikanan Provinsi Sulawesi Utara berperan sebagai pedagang perantara untuk menyalurkan bantuan kepada masyarakat nelayan/petani rumput laut yang ada di SULUT.

\section{Jumlah Produksi}

1. Pembudidaya/Petani Rumput Laut Jumlah produksi dalam budidaya rumput laut yang ada di Desa Buku Utara Kecamatan Belang Kabupaten Minahasa Tenggara, untuk satu kali penanaman dengan luas lahan sebesar $100 \times 200 \mathrm{~m}$, hasilnya dapat mencapai 2-3 ton, bahkan bisa Pebih jika rumput lautnya sehat.

2. Pedagang Pengumpul Jumlah produksie pedagang pengumpul ini tidak terlalu banyak untuk setiap kali penjualannya karena rumput laut di Sulawesi Utara ini sangat kurang sehingga jumlah untuk satu kali produksi/penjualan \pm 300 $500 \mathrm{~kg}$ saja selama 4-5 bulan bahkan bisa lebih.

\section{Harga Rumput Laut}

1. Pembudidaya/petani rumput laut Harga rumput laut yang dipasarkan oleh pembudidaya ada 2 bagian yaitu:

a. Rumput laut basah dengan harga senilai Rp $7.500,-/ \mathrm{kg}$, dan

b. Rumput laut kering dengan kisaran harga jual sebesar Rp 20.000,-/kg.

\section{Pedagang pengumpul}

Harga jual rumput laut mencapai Rp 30.000,- - Rp 40.000,-/kg untuk penjualan di dalam negeri.

3. Pembeli (Dinas Perikanan Provinsi) Berdasarkan hasil penelitian pedagang perantara tidak menjual kembali rumput laut yang dibeli dari pembudidaya tetapi diberikan bantuan kepada kelompok-kolompok pembudidaya untuk dikembangkan, karena pedagang perantara yang dimaksud di sini adalah Dinas Kelautan dan Perikanan Provinsi Sulawesi Utara.

\section{Pendapatan Usaha}

1. Pembudidaya/petani rumput laut

Tabel 2. Perbandingan Harga Rumput Laut Basah dan Kering

\begin{tabular}{|c|l|c|c|c|r|}
\hline No & \multicolumn{1}{|c|}{ Keterangan } & $\begin{array}{c}\text { Berat } \\
(\mathrm{Kg})\end{array}$ & $\begin{array}{c}\text { Harga } \\
(\mathrm{Rp} / \mathrm{Kg})\end{array}$ & & \multicolumn{1}{c|}{ Jumlah } \\
\hline 1 & Petani rumput laut & 2 ton & 7.500 & $2.000 \mathrm{~kg} \times 7.500$ & $15.000,000$ \\
& - Rumput laut basah & $200 \mathrm{~kg}$ & 20.000 & $200 \mathrm{~kg} \times 20.000$ & $4.000,000$ \\
\hline & - Rumput laut kering & & & & \\
\hline \multirow{2}{*}{ Biaya (Gaji karyawan) + biaya lain-lain } & & & & 800,000 \\
& - Rumput laut basah & - & - & - & $2.150,000$ \\
& - Rumput laut kering & & & & 350.000 \\
& - Sewa mobil angkutan & & & & 300.000 \\
& - Biaya penanaman & & & $15.000,000-1.100,-$ & $14.200,000$ \\
& & & & $4.000,000-2.450,-$ & $1.550,000$ \\
\hline
\end{tabular}

Sumber: Data Primer, 2018 
Berdasarkan hasil penelitian, dapat dilihat pada tabel di atas. Data di atas menunjukan bahwa rumput laut basah lebih menguntungkan dibandingkan dengan rumput laut kering. Dengan melihat data tersebut, pemilik rumput laut jarang menjual rumput laut kering. Karena pembudidaya merasa sangat rugi jika menjual rumput laut kering tersebut.

2. Pedagang Pengumpul

Pedagang pengumpul memasarkan rumput lautnya sesuai kecocokan harga yang ditawarkan, jika harga yang ditawarkan sudah sesuai misalnya Rp 30.000/kg, maka pendapatan yang didapatkan pada 1 ton rumput laut sebesar $\pm \mathrm{Rp}$ 30.000.000.

3. Pembeli (Dinas Perikanan Provinsi)

Pedagang perantara yang dimaksud di sini tidak ada pendapatannya, tetapi ada manfaatya yang dirasakan oleh masyarakat yang menerima bantuan tersebut, sehingga masyarakat yang menerima bantuan tersebut dapat memperoleh pendapatan dari hasil cbudidaya rumput laut nantinya.

\section{KESIMPULAN}

1. Pemanenan rumput laut untuk dikeringkan (rumput laut kering) dan pemanenan rumput laut basah

2. Penjumuran, rumput laut yang sudah dipanen, dijemur hingga kering (untuk rumput laut kering)

3. Pengepakan, Rumput laut yang sudah dikeringkan kemudian dipak menggunakan karung plastik

4. Pengangkutan, setelah rumput laut selesai dipak, kemudia Dimasukan ke dalam mobil untuk dibawa ke tempat penjualan

5. Toko Mahawu, toko ini yang biasa membeli rumput laut kering tersebut, sedangkan rumput laut basah dibeli oleh Dinas Perikanan Provinsi Sulawesi Utara, dan diberikan kepada kelompok masyarakat yang menerima bantuan tersebut.

\section{DAFTAR PUSTAKA}

Atkinson. A.A., Kaplan R. S, Matsumura M, Young S.M. 2007. Management Accounting. Upar Sadle River, New Jersey (US) : Prentice Hall. Dalam Lestiawaty Gude.

Dahuri, R. 2003. Keanekaragaman Hayati Laut. Aset Pembangunan Berkelanjutan Indonesia. PT. Gramedia Pustaka Utama. Jakarta

Hayami, Y., T. Kawagoe, Mooroka dan M. Siregar. 1987. Agriculture Marketing and Processing in Upland Java a Perpective from a Sunda Village. CGPRT No. 8. Bogor: CGPRT Center.

Jana, A.T. 2011. Rumput Laut. Penebar Swadaya. Jakarta.

Juneidi, W. 2004. Rumput Laut Jenis dan Morfologisnya. Jakarta: Departemen Pendidikan Nasional Direktorat Jendral Pendidikan Dasar dan Menengah Direktorat Pendidikan Menengah Kejuruan.

Kenanga, DT. 2012. Faktor-faktor Yang Mempengaruhi Pendapatan Usaha Perikanan Tangkap Dengan Kapal Motor. Studi Kasus Kota Bitung.

Mantjoro, E. 1981. Pengantar Metodologi Penelitian. Fakultas Perikanan dan IImu Kelautan UNSRAT, Manado.

Moleong L.J. 2005. Metode Penelitian Kualitatif, Bandung, Edisi Revisi, Penerbit PT. Remaja Rosdakarya.

Sekaran, U. 2011. Research Methods for Business. Edisi I and 2. Jakarta: Salemba Empat.

Sugiyono, 2008. Metode Penelitian Kunatitatif Kualitatif dan R\&D. Bandung. Alfabeta.

Widarsono, Agus. 2005. Analisis Strategi Rantai Nilai : Suatu Pendekatan Manajemen Biaya. BHMN. Bandung.

Wijaya, T. 2010. Manajemen Strategi. Jakarta. 